\title{
Phonological Soundscapes in Medieval Poetry
}

\author{
Christopher Hench \\ University of California, Berkeley \\ Department of German \\ Berkeley, CA 94720, USA \\ chench@berkeley.edu
}

\begin{abstract}
The oral component of medieval poetry was integral to its performance and reception. Yet many believe that the medieval voice has been forever lost, and any attempts at rediscovering it are doomed to failure due to scribal practices, manuscript mouvance, and linguistic normalization in editing practices. This paper offers a method to abstract from this noise and better understand relative differences in phonological soundscapes by considering syllable qualities. The presented syllabification method and soundscape analysis offer themselves as cross-disciplinary tools for low-resource languages. As a case study, we examine medieval German lyric and argue that the heavily debated lyrical 'I' follows a unique trajectory through soundscapes, shedding light on the performance and practice of these poets.
\end{abstract}

\section{Introduction}

Research attempting to generalize medieval literary form has been severely hindered by the gap between performativity and manuscript evidence, manuscript mouvance, and linguistic normalization in editing practices. ${ }^{1}$ How can formal features be identified and agreed upon if manuscripts differ significantly, and most transcriptions used by scholars today have been heavily edited? Recent scholarship has called for medievalists to move beyond such obstacles and recognize the importance of form in composition, performance, and reception (Stock, 2004; Kragl, 2011; Braun, 2013). Markus Stock focuses on sound, reasoning that if we believe these poems were primarily read

\footnotetext{
${ }^{1}$ See Paul Zumthor (1984) on the medieval voice.
}

or sung aloud (with or without musical accompaniment), any insight into how they sounded to the audience would reveal a crucial aspect of the performance. Stock's reading emphasizes the sounds of words and how the repetition of words is not only a repetition of a concept, but a repetition of a sound, reinforcing an idea's connection to that sound (Stock, 2004, 195). Yet it is not necessarily about hearing and recognizing these patterns, rather that "in the sound dimension the individual rhetorical figure is blurred and a total acoustic impression emerges" (Stock, 2004, 200).

This paper proposes taking advantage of the information in syllables to gauge the aesthetic affect of a poem's soundscape by calculating the percentage of open syllables in stanzas of medieval poetry. It then attempts to correlate these "total acoustic impression[s]" with the medieval voice.

\section{Soundscapes}

For orientation purposes, we may first read aloud the following stanzas from the German poet Reinmar der Alte. As our focus is on the phonological sound and rhythm, we may for now set aside understanding the poem, opening up this experience to those who are not experts in medieval German. ${ }^{2}$

[1] Dêst ein nôt, daz mich ein man vor al der werlte twinget, swes er wil. sol ich, des ich niht enkan, beginnen, daz ist mir ein swaerez spil. Ich hât ie vil staeten muot nu muoz ich leben als ein wîp, diu minnet und daz angestlîchen tuot. ${ }^{3}$

\footnotetext{
${ }^{2}$ Each stanza is excerpted from a different poem.

${ }^{3}$ Des Minnesangs Frühling (MF) 192, 25-214C. "It is distressful that a man may force me before all the world to do as he wishes. Am I to begin things that I cannot, that is for me a difficult game. I've always had steadfast courage. Now I must live as a woman who loves, and does so in fear." All translations are the author's own unless otherwise noted.
} 
[2] Swenne ich sî mit mîner valschen rede betrüge,

sô het ich sî unreht erkant.

Und gevâhe sî mich iemer an deheiner lüge,

sâ sô schupfe mich zehant

Und geloube niemer mîner klage,

dar zuo niht, des ich sage

dâ vor müeze mich got behüeten alle tage. $^{4}$

It is difficult to not be immediately drawn to the unique phonological soundscapes. Dêst ein nôt is marked by many closed syllables, creating a short abbreviated affect, while Swenne ich sî, with a majority of open syllables, generates a more iambic rhythm. Although the musical settings and performance for these medieval poems and many others have not survived, we can gather from the phonology of the stanzas that they must have been very different. The great French philosopher JeanJacques Rousseau wrote extensively about language and music, arguing that some languages were more phonologically suitable to music than others. Rousseau believed that an unsuitable language would be "indistinct" and "piercing" when set to music (Rousseau et al., 1998, 144). ${ }^{5}$ To avoid this, one would have to be selective with words, generating very "insipid and monotonous" music: "its progress would also be slow and tiresome for the same reason, and if one wanted to press the movement a little, its haste would resemble that of a heavy and angular body rolling along on cobblestones" (Rousseau et al., 1998, 144). ${ }^{6}$

Although Rousseau's description is surely exaggerated, many writers after him have shared his sentiment that vowels and open syllables are crucial to the composition of sung music and may even correlate with melismatic syllables. ${ }^{7}$ Ger-

\footnotetext{
${ }^{4} M F 173,13-96 C, 53 b$. "If I were to ever deceive her with my false words, then I would have valued her improperly. And if she were to ever catch me in any lie, then she would immediately shake me up and never believe my lamentation, moreover anything I say. May God protect me from that every day."

${ }^{5}$ Rousseau understands Italian as having one of the greatest phonemic inventories due to its open syllables and bright vowels (Rousseau et al., 1998, 148).

${ }^{6}$ Charles Kensington argues that languages with fewer open syllables, English in particular, can remedy this if lexical breadth is sufficient to substitute words (Salaman, 1876, 123-124).

${ }^{7}$ See forthcoming work by Murray Schellenberg, 'Influence of Syllable Structure on Musical Text Setting.' Ross et al. (2007) suggest that preferred musical intervals are related to formants in vowel phones.
}

manic languages, including medieval Middle High German (MHG), Middle English (ME), and Old Norse (ON), would certainly be considered by Rousseau as languages phonologically less suitable when compared to medieval romance languages such as the Old Occitan of the troubadour tradition, with its many open syllables. This distinction is acknowledged in the various manifestations of the MHG word 'tandaradei', a popular interjection used to voice a bird's singing presence. Variations on 'tandaradei' all allow for significantly more sequences of open syllables than normal for MHG phonology, emphasizing the vocal quality of the singing. Heinrich von Stretelingen reimagines himself in the position of the bird, with the world needing his song, and augments the poem's soundscape by adding more open syllables to his own singing to match the bird's tune (Schweikle, 1978):

[3] Frowe, bluomen unde klê unde heide, diu so wunneklîche grüene lît,

Die wen muoten unde mê,

daz diu vogellîn wol singen suozze widerstrît.

Des fröit sich sêre

mîn gemüete, dâz si sint fröiderîch.

al dur ir êre

singe ich mêre,

sît si ist minneklich.

Deilidurei faledirannurei

lîdundei faladaritturei! ${ }^{8}$

Rousseau's characterization of a less-suited language can also shed light on the formal play in MHG poetry emerging in the early 13th century observed by Hugo Kuhn, Thomas Cramer, Markus Stock, and Manuel Braun (Kuhn, 1967; Cramer, 1998; Stock, 2004; Braun, 2013). Rousseau's claim that a less-suited language would be "force[d]" to exclude many words and would thus become "monotonous" is exactly what the scholarship has identified (Cramer, 1998, 45). Motifs are constantly rehashed and Kuhn claims that nothing new was contributed after the formal shift. It appears that a musical vocabulary re-

\footnotetext{
${ }^{8}$ MHG text from Bartsch (1964). "Lady, flowers, and clovers, and heather, which lay so wonderfully green, and who want very much that the little bird sings well and sweet in response. They are pleased by this very much, my senses, that they are joyful. All by her honor, I sing more, since she is dear. Deilidurei faledirannurei lîdundei faladaritturei!"
} 
stricted by the phonology of a language, in addition to the natural development of the genre, led to formal play aimed at breaking these boundaries. With Konrad von Würzburg's mid-13th century infamous rhyme poem (Schlagreimlied 26,I), in which every word is rhymed, we understand well Rousseau's sense of "a heavy and angular body rolling along on cobblestones."

\section{Syllabification}

To analyze phonological soundscapes on a large scale we must first be able to accurately syllabify words. The sonority sequencing principle (SSP) (Jesperson (1904)) and onset maximization and legal initials (Vennemann (1972) and Kahn (1976)) capture the fundamentals of syllabification in many languages. The SSP proposes a scale in which every phoneme in a language may be ordered. A phoneme's sonority value is based on the degree to which the lips are opened and sound is allowed to pass through the mouth (Jespersen, 1904, 186-187). Accordingly, the most sonorous phoneme is an open [a]. Jesperson groups phonemes first by whether they are voiced or voiceless, then stops, fricatives, nasals, laterals, rhotic consonants, and three levels of vowels (high, medium, and low). A syllable break appears before a trough in sonority (Jespersen, 1904, 187-188). While what follows details the syllabification of MHG, this method is easily generalized to many other languages.

For the purposes of syllabifying MHG, it was determined that a three tiered sonority hierarchy was most accurate. ${ }^{10}$ Computationally, each phoneme in a word is assigned a value from 1 to 3 . Vowels, both long and short, receive a 3. Sonorants ('l', 'm', 'n', 'r', and ' $w$ ') receive a 2 . All remaining consonants receive a 1 . The MHG word 'werltlîchen', viz. 'worldy', is syllabified by the SSP accordingly:

$$
\begin{aligned}
& \text { werl - tlî - (ch)en }{ }^{11} \\
& \begin{array}{llll}
2322 & 123 & 1 & 32
\end{array}
\end{aligned}
$$

\footnotetext{
${ }^{9}$ Rousseau's thoughts on linguistic musicality has shifted focus to phonological rhythm in the field of 'rhythm metrics'. See Arvaniti (2009); Bolinger (1965); Ramus et al. (1999, 268); Grabe and Low (2002); Dasher and Bolinger (1982); Patel (2008); Palmer and Kelly (1992)

${ }^{10}$ When adapting to other languages, the number of tiers as well as their composition must also be adapted.

${ }^{11}$ For MHG, 'ch' is considered a single phoneme $[\mathrm{x}]$. Other cases include 'sch' ([f]) and 'ph' ([f]).
}

While the SSP alone can be very accurate, errors may still occur in the onset. The legality principle argues that "[m]edial syllable initial clusters should be possible word initial clusters" (Vennemann, 1972, 11). Daniel Kahn notes that this principle still leaves several possibilities if a consonant cluster could be broken up into more than one permissable word-initial grouping. To remedy this, Kahn argues that there "is a strong tendency to syllabify in such a way that initial clusters are of maximal length" (Kahn, 1976, 41). Because 'tlî' is not a legal onset in MHG, i.e., 'tlî' does not start any MHG word, the ' $t$ ' is then drawn to the first syllable, and 'werl-tlî-chen' becomes 'werlt-lî-chen'. ${ }^{12}$

While some may consider this the correct syllabification, we argue that an intervocalic 'ch' should be considered ambisyllabic and thus also be split up. This and other individual fixes were informed partly by a metrical analysis. ${ }^{13}$ MHG epic poetry generally alternates between stressed and unstressed syllables, following trochaic tetrameter (Tervooren, 1997). A typical MHG epic verse foot is two syllables in length, a stressed syllable followed by an unstressed syllable. However, feet may also consist of one or three syllables (Domanowski et al., 2009). Only phonologically heavy syllables (ending in a long vowel or a consonant) may fill an entire foot. If a foot is filled by three syllables, either the first two or the last two syllables are often phonologically light. ${ }^{14}$ Thus the line belows necessitates the syllabification 'zec-he' so that the single syllable may be heavy and fill the entire foot:

$$
\begin{aligned}
& \text { daz } \mid \text { ist ein } \mid \text { fremdiu }|\mathrm{zec}| \mathrm{he}^{15} \\
& \times|\dot{x} \times| \dot{x} \quad \times \mid \begin{array}{l}
\dot{\prime} \mid \dot{x}
\end{array}
\end{aligned}
$$

The syllabification 'ze-che' would leave a light syllable to fill an entire foot, which is not permitted. Other syllabifications would break with the natural stress of the language. The final syllabification thus yields 'werlt-lîc-hen'. ${ }^{16}$

A similar decision had to be made for inter-

\footnotetext{
${ }^{12}$ For this implementation, onsets were deemed illegal if they appeared in less than $.02 \%$ of all onsets in the corpus. This threshold helps reduce the acceptance of onsets in foreign words.

${ }^{13}$ See Estes and Hench (2016) for a computational approach to MHG phonology and meter.

${ }^{14}$ Excepted are several end syllables in divided falls such as '-er', '-el', and 'ez' (Domanowski et al., 2009).

${ }^{15}$ Wolfram von Eschenbach $(1994,17,1.5-21)$ "This is a peculiar arrangement."

${ }^{16}$ This last change is important for our analyses in that it changes an open syllable ('lî̀) to a closed syllable ('lîc').
} 


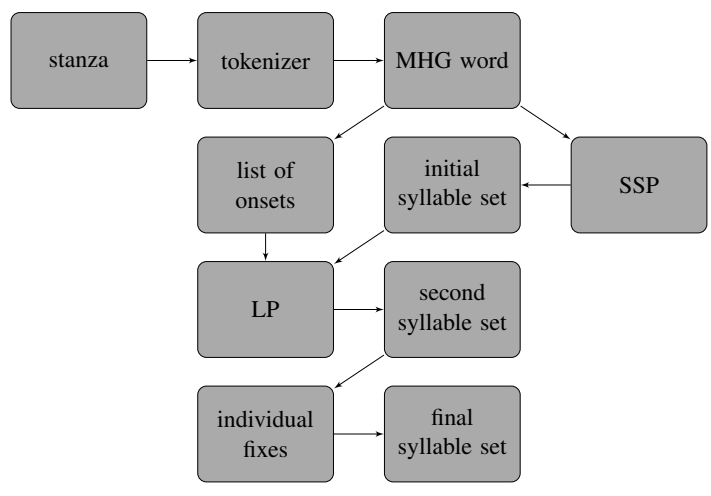

Figure 1: Flow chart for MHG syllabification.

vocalic affricates, which may be viewed as either ambisyllabic or biphonemic. For example, MHG 'sitzen' ('sit') could be syllabified as 'sitzen' ([zi.tsən]), 'sit-zen' ([zit.sən]), or 'sitz-en' ([zits.on]). The first syllabification would yield NHG [zits.ən], which is incorrect. It similarly does not correspond to manifestations in MHG meter, which deems 'sit-zen' preferable, e.g.:

$$
\begin{aligned}
& \text { sie } \mid \text { sêre } \mid \text { solde } \mid \text { let } \mid z^{17}{ }^{17} \\
& \times|\dot{x} \times| \dot{x} \times|\dot{\prime}| \dot{x}
\end{aligned}
$$

The workflow for this process as implemented on MHG is charted in Figure $1 .{ }^{18}$ A text is first tokenized into words, from which a list of permissable onsets is extracted. Each word is then syllabified according to the SSP and controlled for legality of onset. A final small set of language specific morphological fixes are made to yield the final syllable set.

While algorithmic computational syllabification is nothing new, previous methods have not combined syllabification principles in the manner presented here by controlling SSP syllabification with the legality principle (LP). ${ }^{19}$ Moreover, this

\footnotetext{
${ }^{17}$ (Hartmann and Mertens, 2005, 250, 1. 361) "[that his death] would cause them great harm."

${ }^{18}$ The individual fixes include: intervocalic 'ch', intervocalic 'sch', a sequence of one long vowel followed by one short vowel, and the suffixes 'lîch' and 'heit'. These morpheme boundaries interfere with the otherwise normal processes of syllabification. For example, with the fix the common MHG suffix -lich in wiplich results in the syllabification 'wîp-lich', not 'wî-plich', despite onset maximization preferring the latter (' $p l$ ' is a legal MHG onset).

${ }^{19}$ Early work from Bartlett et al. (2008) devised a new method for phonemic translation of English, an important step toward accurate syllabification. Bartlett et al. (2009) produced gold standard results of the SSP, LP, and OM, also creating an SVM-HMM model. Adsett and Marchand (2009) test several algorithms across multiple languages concluding that Syllabification by Analogy is most accurate. Rogova et al. (2013) develop an SCRF model for phonetic transcrip-
}

method is particularly suited to languages lacking a standardized orthography. Testing the algorithm across dialects on the new Referenzkorpus Mittelhochdeutsch (REM) corpus (Klein et al., 2016) yielded an accuracy of $99.4 \%$ on a randomly sampled 1,000 words from the entire corpus of diplomatically transcribed texts. ${ }^{20}$ This algorithm thus offers itself as a useful tool for the syllabification of low-resource languages, particularly those with varied orthography, a significant obstacle for computational text analysis of medieval texts.

\section{Method}

Returning to Reinmar's stanzas above, with such clear voice distinctions one may wonder if these soundscapes are correlated with specific content. To this end, we propose treating each stanza of poetry as a single observation. The soundscape for a stanza is quantified simply by calculating the percentage of open syllables, i.e., syllabes ending in a vowel. Reinmar's stanza [1] above has 9 open syllables and 50 closed syllables, and is thus assigned the value of $15.25 \%$. Stanza [2] has 42 open syllables and 31 closed syllables and is assigned $57.53 \%$. Each stanza in the corpus is then lemmatized and the lemmata are assigned to one of seven buckets at 5\% intervals based solely on this percentage. ${ }^{21}$ Finally, normalized lemmata frequencies are calculated for each bucket and are

tions. Kondrak et al. (2016) seek to improve the gold standard syllabification by including morphological segmentation information.

${ }^{20}$ Syllabifying diplomatically transcribed texts introduces several orthographic obstacles for computers. Most symbols have a 1-1 signification to a standard grapheme, which for computational purposes, were resolved. The greatest obstacle was resolving ' $v$ ' and ' $u$ ' notations, as the consonant ' $v$ ' is at the other end of the sonority hierarchy than the vowel ' $\mathrm{u}$ '. This project assumes a conservative approach by using a corpus of standardized texts from the Mittelhochdeutsche Begriffsdatenbank (MHDBDB) (1992-2017) to determine permissable environments of the ' $\mathrm{v}$ ' grapheme. If a given environment with a ' $v$ ' grapheme in the diplomatic translation does not exist in the standardized environments, the ' $v$ ' is converted to a ' $u$ '. All other cases remain, and no other changes are made to the diplomatic transcriptions. Other spelling variations do not undermine the algorithm, as they commonly remain at the same level of the sonority hierarchy. This project therefore errs on the side of undercorrection. Note, however, that one should not compare results to Bartlett et al. (2009) as MHG is significantly easier to syllabify than English due to orthography and vocabulary. These results also include repeated words to demonstrate relevance to its application in the method.

${ }^{21}$ Lemmata in the MHDBDB corpus are annotated by hand for each text included in this analysis. 


\begin{tabular}{lr}
\hline & stanzas \\
\hline count & 7856 \\
median syllables per stanza & 81 \\
median lines per stanza & 9 \\
median syllables per line & 8 \\
median percent open syllables & $32.88 \%$ \\
\hline
\end{tabular}

Table 1: Summary statistics for soundscape stanza analysis

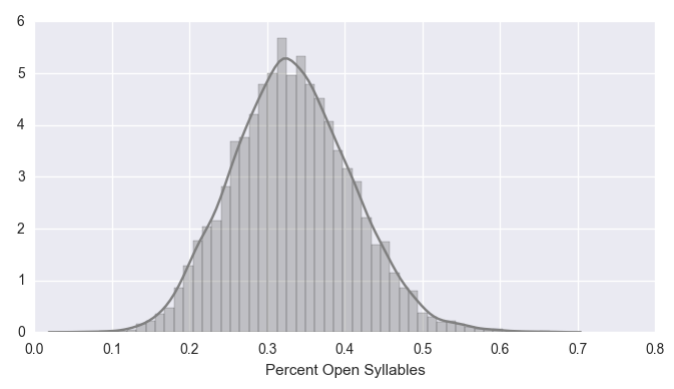

Figure 2: Distribution of soundscapes in the MHDBDB lyric corpus

examined across buckets. ${ }^{22}$

We take all lyric poetry from the Mittelhochdeutsche Begriffsdatenbank (MHDBDB) (1992-2017) corpus of medieval German texts. ${ }^{23}$ Relevant summary statistics for this subset of the corpus are reproduced in Table 1 . The distribution of soundscapes is shown in Figure 2 and the selected buckets and counts are given in Table 2 .

Because the MHDBDB corpus is a collection of primarily edited texts with a range of dialects it is important to determine the degree to which editorial linguistic normalization practices might influence our measure of soundscapes. This problem is not unique to medieval German, and stands as a further significant obstacle to text analysis. A diplomatic transcription of Reinmar's stanza [1] from the Codex Manesse (Handschrift C) serves to illustrate:

\section{D est ein not das mich ein man}

\footnotetext{
${ }^{22}$ Lemmata frequencies are normalized by the length of the bucket. Each bucket is bootstrap resampled 1,000 times with replacement to generate $95 \%$ confidence intervals.

${ }^{23}$ The texts are all those designated as 'Lyrik' in the MHDBDB, with duplicate editions removed. For the purposes of this analysis, this paper considers only those stanzas $>2$ lines and $<50$ lines. While some poems have extended stanzas, especially in the longer political or social commentary poems, considering a stanza $>50$ lines distracts from the focus of studying a smaller unified group generating a clear soundscape.
}

\begin{tabular}{lr}
\hline percent open & stanzas \\
\hline$<20 \%$ & 272 \\
$<25 \%$ & 803 \\
$<30 \%$ & 1582 \\
$<35 \%$ & 2055 \\
$<40 \%$ & 1592 \\
$<45 \%$ & 974 \\
$\geq 45 \%$ & 516 \\
\hline total & 7794 \\
\hline
\end{tabular}

Table 2: Counts of stanzas per soundscape bucket
vor al d w lte twinget swes er wil.
sol ich des ich niht enkan
beginnen dc ist mir ein sweres spil.
ich hat ie vil stetē mvt.
nv mvis ich lebē als ein wib
dvं minet vin das angestlichen tvt. ${ }^{24}$

Aside from shorthand, the primary differences are in vowel orthography and length. Unfortunately, diplomatic transcriptions of MHG lyric, as well as other traditions, are far too few to cover the breadth of the MHDBDB or to serve as the data for a large analysis of MHG lyric. Nevertheless, an impressive effort has been made by the Lyrik des deutschen Mittelalters (LDM) (1992-2017) project to provide a complete online edition of MHG lyric with side-by-side diplomatic transcriptions and edited editions of all extant manuscripts in which a poem survives. The LDM project has completed all of the stanzas attributed to Dietmar von Aist (42), Rubin (68), and Der wilde Alexander (35) in the largest manuscript of MHG lyric, the Codex Manesse. Across these texts we compare the soundscapes for each stanza in the diplomatic transcription and the normalized MHG. Table 3 gives the mean discrepancy in our measure (the percentage of open syllables) weighted by syllable count, demonstrating that it is unlikely that with buckets of $5 \%$ a soundscape would be placed in a bucket more than one bucket away from the correct placement. This test is an important step in building confidence to implement text analysis techniques on noisy medieval manuscripts. By abstracting from the grapheme and varied orthography, this method is still able to garner an accurate representation of a soundscape regardless of editing practices, perhaps even proxying for the other

\footnotetext{
${ }^{24}$ Transcription from Pfaff $(1898,197)$.
} 


\begin{tabular}{lrl}
\hline & stanzas & sound diff. \\
\hline Dietmar von Aist & 42 & $.79 \% \pm 1.00 \%$ \\
Rubin & 68 & $.82 \% \pm .89 \%$ \\
Der wilde Alexander & 35 & $1.09 \% \pm .99 \%$ \\
\hline lyric total & 145 & $.86 \% \pm .95 \%$ \\
\hline
\end{tabular}

Table 3: Comparison of soundscape measure in diplomatic transcriptions and normalized editions in manuscript $\mathrm{C}$, weighted by syllable count in stanza.

layers of mediation inherent in medieval literature.

\section{Soundscapes and Voice}

Returning to Reinmar's stanzas, it is noteworthy that Dêst ein nôt is a male voice and Swenne ich sî is a female voice. Reinmar was not the only one to distinguish speaker roles through soundscapes: ${ }^{25}$

[4] Owê,

si kuste âne zal

in dem slâfe mich.

dô vielen hin zetal

ir trehene nider sich.

iedoch getrôste ich sie,

daz si ir weinen lie

und mich alumbe vie.

dô tagte ez. ${ }^{26}$

[5] Owê,

daz er sô dicke sich

bî mir ersehen hât!

als er endahte mich,

sô wolt er sunder wât

mîn arme schouwen blôz.

ez was ein wunder grôz,

daz in des nie verdrôz.

dô tagte ez. ${ }^{27}$

It is no coincidence that Heinrich von Morungen uses this soundscape difference to highlight

\footnotetext{
${ }^{25}$ Heinrich von Morungen, $M F$ 143,22-93C ff.

${ }^{26} 59.18 \%$ open syllables. "Woe, she kissed me innumerable times in my sleep. Then her tears fell downward. Yet I comforted her, that she let her crying be, and embraced me. Then the day dawned."

${ }^{27} 27.08 \%$ open syllables. "Woe, that he falls for me over and over! As he discovered me, he wanted to see my arms uncovered and bare. It was a great wonder that he never stopped. Then the day dawned."
}

the 'Wechsellied', viz. 'alternating song', quality of his dawn song. This change in soundscape is a feature that largely goes unnoticed by modern readers, as these songs are no longer performed or read aloud. Manuel Braun, describing Ulrich von Liechtenstein's Wizzet frouwe wol getan, similarly shows a clear formal distinction between male and female voices: "The man speaking in the first stanza demonstrates his abilities by using only a single rhyme. The woman in the second stanza does the opposite, not rhyming at all. Thus her speech appears artless and inferior [...]" (Braun, 2013, 223). Thomas Cramer illuminates the same poem, emphasizing that such formal mastery would not have been understood by the average audience member, especially not in a purely oral tradition (Cramer, 1998, 16). Yet this paper argues that these formal distinctions would have been experienced as such by an audience accustomed to such performances, and that these soundscapes have thematic and voice associations.

Among the many possibilities of correlating thematics and voice with soundscapes, we choose here to investigate voice through one of the most common groups of words in the entire corpus: pronouns. Figure 3 shows the relative frequency of the lemmatized pronouns for 'I' ('ich'), 'he' ('er'), and 'she' ('sie') for each soundscape grouping. Shaded regions depict $95 \%$ confidence intervals determined by bootstrap resampling 1,000 stanzas from each bucket. Among the pronouns there is a clear trend in 'ich' and 'er'. To reiterate, 'ich' in this analysis includes all inflected forms- 'ich', 'mich' (me, acc.), 'mir' (me, dat.), etc. Figure 3 implies that with a greater share of open syllables in any given stanza, the share of all words referring to a first person subject ' $I$ ' increases. The opposite holds true for 'he', while 'she' remains relatively constant across buckets. ${ }^{28}$

For further confirmation of this method, we also chart the trends of each grammatical gender's definite article with the hypothesis that due to the definite article inflections and nominal adjective endings attributed to each gender, the feminine article lemma would increase as the mascu-

\footnotetext{
${ }^{28}$ Several tests were conducted to further ensure and explore the accuracy of these results. The most obvious potential complication from the above analysis is that the size, content, and style of these texts vary significantly, and larger texts will inevitably have a larger influence on the analysis. The analysis was rerun holding out a different text each iteration, producing similar results. The five largest texts were also removed, yielding similar results.
} 


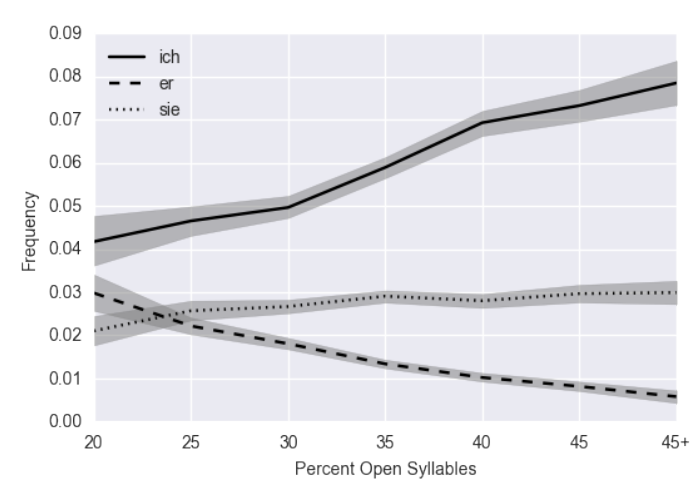

Figure 3: Lemmatized pronouns by soundscape bucket

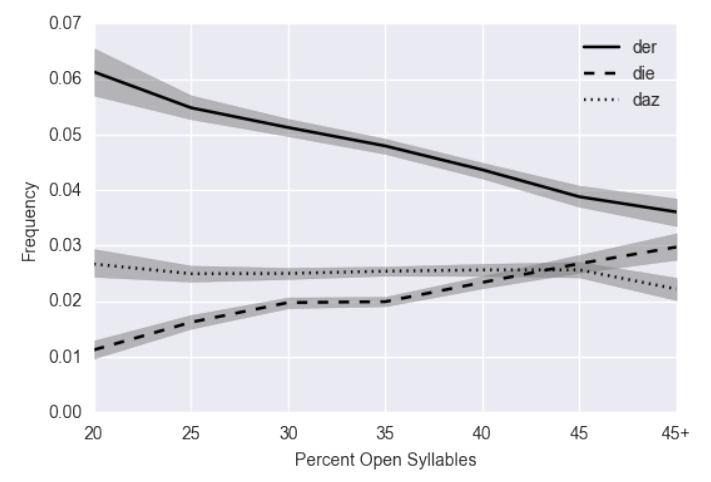

Figure 4: Lemmatized definite articles by soundscape bucket

line article lemma decreases, and the neuter article lemma would remain relatively stable across soundscape buckets. ${ }^{29}$ Figure 4 confirms this hypothesis and demonstrates the inevitability that underlying grammatical genders have a significant impact on the soundscape of a MHG stanza.

The duration of this study will focus on the soundscapes of the first person pronoun and the lyrical 'I' ${ }^{30}$ 'ich' and all of its inflected forms are

\footnotetext{
${ }^{29}$ Following Mittelhochdeutsche Grammatik (Paul et al., 1982), all masculine definite article inflections are closed syllables, only a nominative nominal adjective ending is open. Feminine neuter and accusative article inflections are open syllables, as is the pronominal nominative adjective ending. All neuter definite article inflections are closed syllables, both the nominative and dative nominal adjective endings are open syllables.

${ }^{30}$ Admittedly, 'er' and 'sie' are complicated cases, as MHG can refer to non-human objects using the masculine and feminine pronouns for the gender, though in this genre of lyric that is rather uncommon. While stanzas with a female voice have not been separately annotated, Katharina Boll's thorough study Also redete ein vrowe schoene identifies two characteristics marking a stanza in a female voice: "For one, the extreme distinction through a male first-person singer with the 'Inquit' formula. The gender specific status of the speaker can also be shown internally, for example through
}

unambiguous in MHG in their reference to a first person speaker. Moreover, save the feminine accusative possessive pronouns, each form of 'ich' is a closed syllable. To be growing in presence inside of a soundscape with a greater share of open syllables implies that it must be counteracting itself with more open syllables to offset its own closed quality.

\section{The Medieval German Lyrical ' $I$ '}

In MHG lyric there are two opposing interpretations of the lyrical 'I', with a wide spectrum in between. ${ }^{31}$ One interpretation claims that the lyrical ' $\mathrm{I}$ ' and all other roles are entirely fictional, created for entertainment or pedagogical purposes. It follows that we know nearly nothing about the real authors and performers. Günther Schweikle, while not assuming this extreme stance, argues that Minnesang (medieval German love lyric) is a constructed realm of stage play (Schweikle, 1995, 92). ${ }^{32}$

Schweikle's position has been softened significantly by Jan-Dirk Müller, who, while acknowledging and emphasizing the fictional aspect of Minnesang, seeks to reconcile this aspect with the many attempts by the Minnesänger (the poets of Minnesang) to integrate a very real aspect of their life, society, and work into their poems. Elements of reality, Müller argues, are necessary to convince and captivate the audience. One great difference in Minnesang from other forms of poetry is that the poets commonly represent not a single fictional or non-fictional person, but an entire community (ladies, knights, singers, etc.), as these roles often collapse into one through an abundance of references, not hinting at reality, but at what reality could or should be (Müller, 2001, 110, 113, 127). Müller argues for an inclusive interpretation of this

the apostrophization of the male partner" (Boll, 2007, 117). This 'Inquit' formula, "sprach diu vrouwe" ("the lady said"), is not measured in the preceding analysis. However, the common internal pronoun reference ('er' and its inflections) is captured clearly and is consistent in soundscapes with a lower share of open syllables, exemplified by Reinmar and Heinrich above. While we hesitate to make any stronger claims due to referential ambiguity, this line should be further investigated and the groundwork for constructing a supervised classifier has been laid.

${ }^{31}$ This debate began with Warning (1979). See also Strohschneider (1996) and Müller (2001), (2004).

${ }^{32}$ Horst Brunner adopts a similar stance for MHG lyric outside the Minnesang genre (Brunner and Tervooren, 2000, 7). Sabine Obermaier argues that even when speaking selfreflexively, these poets recreate themselves many times over in different professions (Obermaier, 2000). 
'I' as an individual, an author, a singer, and community, also emphasizing the agenda behind the 'ich'.

Intensifying some of Müller's claims, Harald Haferland maintains that the fiction of Minnesang is actually much closer to reality and that the Minnesänger, through situational references, often speak directly to the audience as themselves (Haferland, 2004, 77). Haferland argues that Minnesang's success was contingent upon believability. The effect of the poems would be much stronger if the poet could relate situations directly to the audience without a fictive role.

What consequences do these soundscapes have for the configuration of the first person in MHG poetry? Considering Stock's recent research on sound, we recognize that repeating the first person pronoun is not only repeating a semantic concept, but the actual sounds of 'ich', 'mich', 'mir', etc. Stock's example is Gottfried von Neifen, one of the lead poets in shifting the genre toward more formalist ambitions. He is interested in Gottfried's use of sound through word repetition, specifically through the repetition of 'fröide' ('joy') and 'liebe' ('love'), in the sense of Vickie Ziegler's 'Leitwort', viz. 'leading-' or 'guiding word' (Ziegler, 1975). While the 'Leitwort' is generally understood to have semantic importance due to its high frequency relative to the rest of the corpus or song, what if the ubiquitous lyrical 'I', this heavily controversial figure, is elevated to 'Leitwort', or perhaps 'Leitklang' ('leading sound'), via its unique soundscape presence?

[6] Ich solt aber dur die süezen grüezen meien walt heid ouwe und der kleinen vogel süezez singen, lieze eht mir an ir gelingen trût mîn trôst, mîs herzen frouwe, daz si mînen kumber wolde büezen: seht, sô wurde ich noch an fröiden rîche. truter lip, nu tuot genædecliche: rôter munt, du maht mîn leit verdringen. ${ }^{33}$

\section{[7] Süeziu minne, sît dîn minne}

\footnotetext{
${ }^{33}$ Text from Kraus (1951-1958). 35.71\% open syllabes. "I should but sing sweetly through the sweet, welcoming May forest, heather, water, and to the small birds. May it only reach her as comfort, my dear, lady of my heart, that she would wish to relieve my suffering: see, so will I be rich in joy. My dear, now do so graciously: red mouth, you drive away my suffering."
}

sinne krenket zallen stunden, wie sold ich dan iemer frô belîben?

lieber lîp vor allen lîben,

heilet mir mîns herzen wunden, daz mîn fröide lige an dem gewinne. tuot ir daz, sô wirde ich froidebære. sælic wîp, nu scheidet mich von swære. Minne, dû maht mir mîn leit vertrîben. ${ }^{34}$

[8] Ich hân fröide von ir eine: seine troestet mich ir güete.

dâ von muoz mir spilndiu fröide swinden.

lieze sie mich gnâde vinden, seht, so fröite mîn gemüete, daz mir wurde ir rôter kus, ein kleine; so wær ich vil manger sorgen âne. triutelehter lîp, ich lebe in wâne daz ich fröide von iu müge enpfinden. ${ }^{35}$

Formal play is clearly on display in Gottfried's song through rhyme, alliteration, and soundscape. The percentage of open syllables gradually increases in each stanza, taking on an entirely new soundscape in the last stanza, while retaining nearly the same number of syllables per line and presumably the same metrical scansion. While we clearly see the increased presence of the 'Leitwort' 'fröide', it is easy to overlook the simultaneous increased presence of the first person (following the trend in Figure 3). Not only does this subject increase in count, but also in space and time intervals, both crucial aspects of the performance. In the first two stanzas the subject appears in more concentrated sections, while Gottfried leaves himself (or his fictive role) out of consecutive verses to describe nature, a bird, and love. Not so in the final stanza, in which Gottfried's subject asserts himself in every verse, refocusing the audience's attention on the subject before them, not only through these self-references, but also by intensifying the sound-

\footnotetext{
${ }^{34} 39.29 \%$ open syllables. "Sweet love, since your love weakens the senses at all hours, how should I then ever be left happy? My dear above all others, heal me of my heart's wounds, that my happiness is won. If this is done, so will I be joyful. Fortunate lady, part me now from grief. Love, you drive away my suffering."

${ }^{35} 49.41 \%$ open syllables. "I had joy from her alone: her goodness comforted me, from which the playful joy must vanish. If she allowed me to find grace, you see, so would my disposition be joyed, that I would receive her red kiss, a small one; so would I be without many worries. My dear, I live in hope that I may feel joy from you."
} 
scape. Each self-reference throughout the entire poem is itself a closed syllable for which Gottfried must compensate further as the song progresses. The clear increased presence of 'fröide' is certainly one solution. Stock hesitantly borrows from Kuhn's terminology, that the 'fröide' 'Leitwort' in Gottfried's complementary KLD song 3 through its repeated employment in formal moves becomes "objective". ${ }^{36}$ The objective 'fröide' becomes the central theme of the poem, superseding the singer himself. Yet in his poem above, Gottfried appears to struggle with the objectivisation of 'fröide' in order to maintain the singer as the central reference, in fact it is the subject, to which this increased presence of the sound (and 'reality') of 'fröide' is constantly subjected. Although as we have now come to learn, it is not only the sound of 'fröide', rather the sonorous sound of open syllables, with which the subject is temporally and sequentially surrounded, and which may simply serve as a counter-weight to the increased presence of the ego-centric subject.

\section{Conclusion}

This paper has demonstrated that abstracting from orthographic variation and individual graphemes to the building blocks of language can help unite a diverse corpus for analysis. Testing this method on various levels of mediation demonstrates its potential for text analysis on the heavily mediated medieval corpus. Implementing this method reveals unique soundscape experiences of a medieval audience. This paper thus answers calls for new formal approaches to sound across disciplines, and provides a generalizable workflow for the syllabification of low-resource languages. The results from a case study of medieval German lyric support a counter-intuitive trend in the positioning of the lyrical 'I', and paves the way for feature extraction and classification of gendered voice. ${ }^{37}$

\section{Acknowledgments}

We would like to thank the Mittelhochdeutsche Begriffsdatenbank and Klaus Schmidt, Digital Humanities at Berkeley, and David Bamman for their continued support of this project.

\footnotetext{
${ }^{36}$ See Stock $(2004,188)$ and Kuhn (1967).

${ }^{37}$ The source code for this project is available at https://github.com/henchc/ ACL-LaTeCH-CLfL-2017.
}

\section{References}

Connie R Adsett and Yannick Marchand. 2009. A comparison of data-driven automatic syllabification methods. In International Symposium on String Processing and Information Retrieval. Springer, pages 174-181.

Amalia Arvaniti. 2009. Rhythm, Timing and the Timing of Rhythm 66(1):46-63. https://doi.org/10.1159/000208930.

Susan Bartlett, Grzegorz Kondrak, and Colin Cherry. 2008. Automatic syllabification with structured svms for letter-to-phoneme conversion. In $A C L$ 2008. pages 568-576.

Susan Bartlett, Grzegorz Kondrak, and Colin Cherry. 2009. On the syllabification of phonemes. In Proceedings of Human Language Technologies: The 2009 Annual Conference of the North American Chapter of the Association for Computational Linguistics. Association for Computational Linguistics, pages 308-316. http://dl.acm.org/citation.cfm?id=1620799.

Karl Bartsch. 1964. Die Schweizer Minnesänger. Huber.

D. L. Bolinger. 1965. Pitch accent and sentence rhythm. In Abe, Kanekiyo, Forms of English: accent, morpheme, order, Harvard University Press, pages 139-180.

Katharina Boll. 2007. Also redete ein vrowe schoene: Untersuchungen zu Konstitution und Funktion der Frauenrede im Minnesang des 12. Jahrhunderts. Number 31 in Würzburger Beiträge zur deutschen Philologie. Königshausen \& Neumann.

Manuel Braun. 2013. Aufmerksamkeitsverschiebung. Zum Minnesang des 13. Jahrhunderts als Form- und Klangkunst 21:203-230.

Horst Brunner and Helmut Tervooren. 2000. Einleitung: Zur situation der sangspruch- und meistergesangsforschung 119(2000):1-9.

Thomas Cramer. 1998. Waz hilfet âne sinne kunst?: Lyrik im 13. Jahrhundert Studien zu ihrer Ästhetik. Number Heft 148 in Philologische Studien und Quellen. E. Schmidt.

Richard Dasher and Dwight Bolinger. 1982. On pre-accentual lengthening 12(2):58-71. https://doi.org/10.1017/S0025100300002462.

Anna Domanowski, Yochanan Rauert, Hanno Rüther, and Tomas Tomasek. 2009. Mittelhochdeutsche Metrik Online. https://www.unimuenster.de/MhdMetrikOnline/.

Alex Estes and Christopher Hench. 2016. Supervised machine learning for hybrid meter http://www.aclweb.org/anthology/W/W16/W160201.pdf. 
E. Grabe and E. Low. 2002. Durational variability in speech and the rhythm class hypothesis Vol. 7:515546.

Harald Haferland. 2004. Minnesang als posenrhetorik. In Albrecht Hausmann, Cornelia Logemann, and Christian Rode, editors, Text und Handeln: zum kommunikativen Ort von Minnesang und antiker Lyrik, Winter, number Heft 46 in Beihefte zum Euphorion, pages 65-105.

Hartmann and Volker Mertens. 2005. Der arme Heinrich. Bibliothek des Mittelalters. ChadwyckHealey, Cambridge, England.

$\begin{array}{cccc}\text { Otto } & \text { Jespersen. } & \text { 1904. } & \text { Lehrbuch } \\ \text { der } & \text { Phonetik; } & \text { Leipzig, Teubner. }\end{array}$ http://archive.org/details/lehrbuchderphone00jespuoft

Daniel Kahn. 1976. Syllable-based generalizations in english phonology.

Thomas Klein, Klaus-Peter Wegera, Stefanie Dipper, and Claudia Wich-Reif. 2016. Referenzkorpus mittelhochdeutsch (1050-1350). https://www.linguistics.ruhr-uni-bochum.de/rem/.

Garrett Nicolai Lei Yao Grzegorz Kondrak. 2016. Morphological segmentation can improve syllabification. ACL 2016 page 99.

Florian Kragl. 2011. wort unde wîse. Formen des sangbaren Verses in der deutschen Literatur des Mittelalters 52:31-80.

Carl von Kraus. 1951-1958. Gottfried von Neifen, volume Deutsche Liederdichter. M. Niemeyer.

Hugo Kuhn. 1967. Minnesangs Wende. Hermaea n.F., Bd. 1. Niemeyer.

Hugo Moser, Helmut Tervooren, and Carl von Kraus, editors. 1977. Des Minnesangs Frühling. Hirzel, 36., neugestaltete u. erw. aufl edition.

Jan-Dirk Müller. 2001. "ir sult sprechen willekomen": Sänger, sprecherrolle und die anfänge volkssprachlicher lyrik. In Ute von Bloh and Armin Schulz, editors, Minnesang und Literaturtheorie, Niemeyer, pages 107-128.

Jan-Dirk Müller. 2004. Die fiktion höfischer liebe und die fiktionalität des minnesangs. In Text und Handeln. Zum kommunikativen Ort von Minnesang und antiker Lyrik, pages 47-64.

Sabine Obermaier. 2000. Der dichter als handwerker - der handwerker als dichter. autorkonzepte zwischen sangspruchdichtung und meistersang. 119(2000):59-72.

Carloline Palmer and Michael Kelly. 1992. Linguistic prosody and musical meter in song 31(4):525-542. https://doi.org/10.1016/0749-596X(92)90027-U.

Aniruddh D. Patel. 2008. Music, language, and the brain. Oxford University Press.
Hermann Paul, Hugo Moser, Ingeborg Schröbler, and Siegfried Grosse. 1982. Mittelhochdeutsche Grammatik. Max Niemeyer, Tübingen.

Fridrich Pfaff. 1898. Die grosse Heidelberger Liederhandschrift, in getreuem textabdruck. C. Winter. https//catalog.hathitrust.org/Record/100607933.

F. Ramus, M. Nespor, and J. Mehler. 1999. Correlates of linguistic rhythm in the speech signal 73(3):265292.

Kseniya Rogova, Kris Demuynck, and Dirk Van Compernolle. 2013. Automatic syllabification using segmental conditional random fields. Comput. Linguist. Neth. J 3:34-48.

Deborah Ross, Jonathan Choi, and Dale Purves. 2007. Musical intervals in speech 104(23):9852-9857. http://www.pnas.org/content/104/23/9852.short.

Jean-Jacques Rousseau, John T. Scott, and JeanJacques Rousseau. 1998. Essay on the origin of languages and writings related to music. Number vol. 7 in The collected writings of Rousseau. University Press of New England.

Charles Kensington Salaman. 1876. On the English Language as a Language for Music 3(1):120-139. https://doi.org/10.1093/jrma/3.1.120.

Günther Schweikle. 1978. Heinrich von stretelingen. In Die deutsche Literatur des Mittelalters, Verfasserlexikon, W. de Gruyter, volume 3. Zweite, völlig neu bearbeitete auflage edition.

Günther Schweikle. 1995. Minnesang, volume 244. Metzler.

Margerete Springeth, Nikolaus Morocutti, and Daniel Schlager. 1992-2017. Mittelhochdeutsche begriffsdatenbank (mhdbdb). universität salzburg. http: //www.mhdbdb.sbg.ac.at/. Accessed: 2016-10-01.

Markus Stock. 2004. Das volle wort - sprachklang im späteren minnesang. In Albrecht Hausmann, Cornelia Logemann, and Christian Rode, editors, Text und Handeln: zum kommunikativen Ort von Minnesang und antiker Lyrik, Winter, number Heft 46 in Beihefte zum Euphorion, pages 65-105.

Peter Strohschneider. 1996. "nu sehent, wie der singet!": vom hervortreten des sängers im minnesang. In "Aufführung" und "Schrift" in Mittelalter und früher Neuzeit, pages 7-30.

Helmut Tervooren. 1997. Minimalmetrik zur Arbeit mit mittelhochdeutschen Texten. Kümmerle Verlag, Göppingen.

Theo Vennemann. 1972. On the Theory of Syllabic Phonology. Linguistische Berichte 18:1-18.

Rainer Warning. 1979. Lyrisches ich und öffentlichkeit bei den trobadors. In FS Hugo Kuhn (1979), pages $120-159$. 
Wolfram, Karl Lachmann, Eberhard Nellmann, and Dieter Kuhn. 1994. Parzival. Bibliothek deutscher Klassiker. Deutscher Klassiker Verlag, Frankfurt am Main, 1 edition.

Vickie L. Ziegler. 1975. The leitword in Minnesang: stylistic analysis and textual criticism. The Penn State series in German literature. Pennsylvania State University Press.

Paul Zumthor. 1984. La poésie et la voix dans la civilisation médiévale, volume 9. Julliard. 